\section{A Cigarette by any other name is still a cigarette}

\author{
Desmond Jenson 으
}

For essentially the entire history of tobacco product regulation in the USA, the tobacco industry has been manipulating its products to exploit regulatory loopholes. From the invention of so-called 'light' cigarettes to fool government smoking machines, to the addition of sepiolite (a clay found in cat litter) to increase the weight of cigars in order to receive favourable federal taxation, manufacturers have been finding ways to skirt effective regulation. ${ }^{12}$ While the Family Smoking Prevention and Tobacco Control Act (FSPTCA) represents a potential leap forward in regulatory oversight, the law's bifurcated implementation from 2009 until 2016 meant that tobacco product manufacturers had every incentive to shift their focus away from cigarettes and smokeless tobacco, which were subject to a comprehensive regulatory scheme, to other products such as cigars and e-cigarettes with no federal oversight whatsoever. Little cigars are a textbook example.

Little cigars are cigars in name only. They are the size and shape of cigarettes, are filtered, and sold in packs of twenty. The only distinction between these products and cigarettes is that the paper wrapper of a little cigar is brown rather than white, because manufacturers add a small amount of tobacco to the paper during the manufacturing process. This is done so that the products are classified as cigars for virtually every regulatory scheme in the U.S. By most legal definitions, a cigarette is "any roll of tobacco wrapped in paper or in any substance not containing tobacco." 3 Thus, a tobacco wrapper, even a nominal one, transforms what would otherwise be a cigarette, into a cigar.

The incentive for manufacturers to convert some of their cigarette brands into little cigars significantly increased with the passage of the FSPTCA and the Children's Health Insurance Program Reauthorization Act of 2009, which, respectively, imposed significant restrictions on the sale, distribution, advertising, and marketing of cigarettes and imposed

Public Health Law Center, Saint Paul, Minnesota, USA

Correspondence to Desmond Jenson, Public Health Law Center, Saint Paul, MN 55105, USA; desmond.jenson@mitchellhamline.edu higher taxes on cigarettes than cigars. Several discount cigarette brands suddenly became filtered little cigars that were taxed at a lower rate, sold as "lights," and contained characterising flavours. Because most regulatory definitions of cigar focus on the tobacco wrapper, state, local, and federal regulators throughout the U.S. mostly acquiesced to the industry's scheme. A tiny pinch of tobacco added during the manufacturing process eviscerated strong regulatory controls that took decades to put into place.

However, one regulator took the bold step of challenging this assumption. In December 2016, the U.S. Food and Drug Administration (FDA) sent warning letters to four manufacturers of little cigars informing them that, while they were marketing their products as cigars, those products actually met the federal definition of cigarette. In addition to the language mentioned above, the FSPTCA also defines a cigarette as 'any roll of tobacco wrapped in any substance containing tobacco which, because of its appearance, the type of tobacco used in the filler, or its packaging and labelling, is likely to be offered to, or purchased by, consumers as a cigarette'. ${ }^{4}$ This is the legal equivalent of 'if it walks like a duck and quacks like a duck, it is, in fact, a duck'.

On the most basic level, this action subjects products that are functionally identical to cigarettes to the level of regulation that our laws contemplate. By the time that the Food and Drug Administration (FDA) sent these letters, the agency had finally extended its regulatory jurisdiction to all cigars but that action established a baseline for regulation that is still far below that of cigarettes. Importantly, and highlighted in the FDA's warning letters, cigars are still widely available in all sorts of flavours, while cigarettes can legally be sold with characterising flavours coming only from the tobacco or the addition of menthol. It has been well established that flavours attract youth to cigarettes, and so the FDA's action would have closed a dangerous loophole by finally eliminating flavours in products that are cigarettes in every way except their name.

This action had the potential for broader implications as well. For example, the Master Settlement Agreement (MSA) between cigarette manufacturers and 46 states, the District of Columbia and the territories has a definition of cigarette that also incorporates the 'walks like a duck' language. Were the FDA to follow through on its enforcement action and successfully defend itself in court, it is possible that this would have opened the door for the settling states to subject these products to the requirements of the MSA. Federal tax law also uses this language, which creates a potential to close the tax loophole for these products as well.

Disappointingly, the FDA has failed to pursue this clear violation of federal law. Thanks to Lindblom and colleagues, we can see that the FDA initiated this action and then simply failed to see it through. Since 2009, the tobacco control community has expected the FDA to be a leader in the fight against the epidemic of tobacco use in the USA. This was an occasion in which it seemed that the FDA had finally fulfilled its role as the vanguard against industry exploitation of regulatory loopholes. Years later, we now find out that this was another case where the FDA took an action that made headlines but ultimately had no impact on the health of our nation, a mistake that the FDA seems resigned to making again as it puts restrictions on flavours in e-cigarettes but fails to address cigars in 2020, even as it had proposed to remove all flavours in cigars in 2019. ${ }^{56}$

This misstep is particularly acute, given that cigars are now favoured over cigarettes by high school students. ${ }^{7}$ While the USA has made tremendous progress in reducing youth consumption of cigarettes, cigars have often filled that gap. Our policies often treat these two classes of products differently despite the fact that the products are similar and, in some cases, virtually identical. Policymakers and advocates should learn two important lessons from this example. First, when we attempt to take bold action on the most harmful tobacco products, we do ourselves a disservice by not including cigars and focusing solely on cigarettes. Second, we only know the depths of the FDA's failure because there is a small group of dedicated watchdogs who are willing to hold the agency accountable. Without proper oversight and engagement, our democracy does not function.

Twitter Desmond Jenson @desmondjenson

Contributors DJ wrote and edited this article.

Competing interests None declared.

Patient consent for publication Not required.

Provenance and peer review Commissioned; internally peer reviewed. 
(C) Author(s) (or their employer(s)) 2020. No commercial re-use. See rights and permissions. Published by BMJ.

\section{(D) Check for updates}

To cite Jenson D. Tob Control 2020;29:604-605. Published Online First 26 February 2020

\section{SLinked}

http://dx.doi.org/10.1136/tobaccocontrol-2019055395

Tob Control 2020;29:604-605.

doi:10.1136/tobaccocontrol-2019-055597

\section{ORCID iD}

Desmond Jenson http://orcid.org/0000-0002-72511737

\section{REFERENCES}

1 U.S. v. Philip Morris, Inc., 449 F. Supp. $2 d 1$ (D.D.C. 2006), aff'd in relevant part, 566 F.2d 1095 (D.C. Cir. 2009), cert. denied, 130 S.Ct. 3501 (2010).

2 Edney A. Tobacco firms save $\$ 1$ billion with kitty litter in cigars. Bloomberg Business News, 2013. Available: http://www.bloomberg.com/news/articles/2013-0301/tobacco-firms-save-1-billion-with-kitty-litter-incigars

3 Federal Cigarette Labeling and Advertising Act. 15 U.S.C. § 1332(1)(A)
4 Family Smoking Prevention and Tobacco Control Act. 21 U.S.C. 387(3)(B). Federal Cigarette Labeling and Advertising Act. 15 U.S.C. § 1332(1)(B).

5 U.S. Food and Drug Administration. Modifications to compliance policy for certain deemed tobacco products, 2019. Available: https://www. regulations. gov/contentStreamer?documentld=FDA-2019-D-06610003 \&attachmentNumber $=1 \&$ contentType $=$ pdf

6 U.S. Food and Drug Administration. Enforcement priorities for Electronic Nicotine Delivery Systems (ENDS) and other deemed products on the market without Premarket authorization, 2020. Available: https://www. fda.gov/media/133880/download

7 Wang TW, Gentzke AS, Creamer MR, et al. Tobacco Product Use and Associated Factors Among Middle and High School Students- United States, 2019. MMWR Surveill Summ 2019;68:1-22. 